\title{
Cardiovascular Risk in Children and Adolescents with Type 1 and Type 2 Diabetes Mellitus
}

\author{
Sheela N. Magge, M.D., M.S.C.E. \\ Division of Endocrinology and Diabetes, The Children's Hospital of Philadelphia; Perelman \\ School of Medicine at the University of Pennsylvania
}

\begin{abstract}
Rising rates of both type 1 and type 2 diabetes mellitus in children have led to increased concern regarding cardiovascular disease (CVD) risk during childhood. Diabetic children face prolonged exposure to hyperglycemia, and have increased risk of both microvascular and macrovascular disease. These circumstances may result in a generation of young adults presenting with cardiovascular outcomes, a tremendous personal and public health toll. In this article, we review CVD risk in type 1 and type 2 diabetes, discuss aspects of pathophysiology, and review current methods of CVD risk assessment. We also identify crucial areas in need of future research in order to devise effective prevention and treatment of CVD risk in children.
\end{abstract}

\section{Keywords}

type 1 diabetes mellitus; type 2 diabetes mellitus; lipoprotein subclass particle analysis; adipokines; adiponectin; inflammation; cardiovascular risk; body mass index; pediatrics; lipids; obesity; carotid intimal medial thickness; flow mediated dilation of the brachial artery; pulse wave velocity; pulse wave analysis; echocardiography; left ventricular mass; coronary artery calcification

\section{Introduction}

Cardiovascular risk assessment in diabetic children has become critically important in pediatric preventative medicine. Though the pathophysiology differs, both type 1 (T1DM) and type 2 diabetes (T2DM) confer increased cardiovascular disease (CVD) risk. Moreover, rates of both types of diabetes are rising. T1DM incidence is increasing worldwide ${ }^{1,2}$, particularly in children less than 5 years of age ${ }^{3}$. The rise in pediatric obesity ${ }^{4}$ has led to increased insulin resistance and T2DM in children ${ }^{5,6}$. T2DM has risen from affecting less than $4 \%$ of newly diagnosed diabetic children before the 1990's, to current estimates of $15 \%$ in 10-19 year olds ${ }^{7}$. This is significant because both obesity and diabetes are risk factors for $\mathrm{CVD}^{8}$. In fact, in adults T2DM is considered a coronary heart disease equivalent ${ }^{9}$. Increases in both types of diabetes and their comorbidities during childhood may result in society being faced with a generation presenting with CVD decades younger than previously experienced.

Atherosclerosis begins in youth. The Pathobiological Determinants of Atherosclerosis in Youth Study ${ }^{10}$, an autopsy study of subjects who died of external causes, revealed that intimal lesions were seen among 15 -19 year-olds in the aortas and in more than half of right

Adress: Sheela N. Magge, M.D., M.S.C.E., Division of Endocrinology and Diabetes, The Children's Hospital of Philadelphia, 3535 Market Street, $15^{\text {th }}$ Floor Suite 1578, Philadelphia, PA 19104, Phone: 267-426-5040, Fax: 215-590-0604, magge@email.chop.edu. 
coronary arteries. In young adult men, atherosclerosis severity increased with obesity ${ }^{11}$. The relationship between CVD risk factors and atherosclerosis was also investigated in subjects aged 2 to 39 years, as part of the Bogalusa Heart Study ${ }^{12}$. Body mass index (BMI), systolic and diastolic blood pressure, total cholesterol, triglycerides, low density lipoprotein cholesterol (LDL-C), and high density lipoprotein cholesterol (HDL-C) measured before death, were associated with arterial fatty streaks and fibrous plaques at autopsy.

Furthermore, childhood obesity that persisted into adulthood was associated with elevated carotid intimal medial thickness (CIMT) at age 35 years. However, thin children who became overweight adults did not have elevated CIMT ${ }^{13}$. The Muscatine study found that increased BMI, decreased HDL-C, and increased blood pressure measured at average ages of 15 and 27 years, were associated with coronary artery calcification at a mean age of 33 years ${ }^{14}$. In the Young Finns Study, childhood LDL-C, systolic blood pressure, BMI, and smoking were associated with CIMT in adulthood ${ }^{15}$. Thus, CVD risk factors during childhood track into adulthood and cause morbidity and mortality.

\section{Type 1 Diabetes}

Research shows that $35 \%$ of individuals with T1DM will die of coronary artery disease by age $55 \mathrm{yrs}$, compared to $4 \%$ of women and $8 \%$ of men without diabetes. Mortality rates increase rapidly after $30 y e a r s$ of age, and are worse in those with renal disease ${ }^{16}$. T1DM confers an increased risk of both microvascular and macrovascular disease. The landmark Diabetes Control and Complications Trial (DCCT) established that intensive glucose control in T1DM decreased retinopathy, nephropathy, and neuropathy associated with the disease ${ }^{17}$. Follow up of this patient cohort longitudinally in the Epidemiology of Diabetes Interventions and Complications (EDIC) study demonstrated a relationship between tighter glycemic control and decreased CVD ${ }^{18}$ and atherosclerosis ${ }^{19}$ in T1DM. Hyperglycemia causes glycation of proteins, resulting in the formation of advanced glycation end products, which contribute to atherogenesis ${ }^{20,21}$. Other studies have also confirmed the importance of glycemic control. In adults with T1DM, having an HbA1c $>7.5 \%$ was strongly associated with increased progression of coronary artery calcification measured by CT scan, compared to those with an $\mathrm{HbA} 1 \mathrm{c}<7.5 \%{ }^{22}$. Studies in children are limited, but Shamir et al found that among a group of adolescents with T1DM, tighter glycemic control was associated with decreased oxidative stress and improved lipids ${ }^{23}$. Among the 195 adolescents who participated in the DCCT, those with tighter glycemic control had decreased retinopathy and nephropathy, although they also had increased hypoglycemia ${ }^{17}$.

In addition to hyperglycemia, other contributors to CVD risk in T1DM include mitochondrial dysfunction and oxidative stress, ${ }^{24}$ as well as insulin resistance ${ }^{25}$, the latter traditionally considered more relevant to T2DM. In a subset of the CACTI study, insulin resistance was increased in T1DM compared to nondiabetic controls both with respect to glucose utilization and suppression of non-esterified fatty acids. In addition, insulin resistance was associated with the extent of coronary artery calcification in both type 1 diabetics and controls ${ }^{25}$. In children, Nadeau et $\mathrm{al}^{26}$ used hyperinsulinemic clamp studies to show increased insulin resistance in nonobese type 1 diabetic adolescents compared to nondiabetic controls. The adolescents with T1DM also had decreased functional exercise capacity and cardiovascular dysfunction. Female youth with T1DM compared to nondiabetic controls showed evidence of delayed myocardial relaxation, unrelated to HbA1c and duration of diabetes, although findings were not as strong in male type 1 diabetics ${ }^{27}$. In addition, with increased childhood obesity in society ${ }^{4}$, more children with T1DM may also be obese, potentially increasing the pathologic role for insulin resistance. 


\section{Type 2 Diabetes}

CVD is a leading cause of death among individuals with T2DM ${ }^{28,29}$. Both obesity and insulin resistance are risk factors for T2DM, and are components of the "metabolic syndrome," a constellation of risk factors which also includes dyslipidemia and hypertension, and is predictive of CVD in adults ${ }^{30}$. Dyslipidemia is prevalent among obese children, with $17 \%$ to $43 \%$ having low HDL-C (depending on the cut-offs used) ${ }^{31-33}$. T2DM is caused by a combination of insulin resistance and defective insulin secretion. Insulin resistance is an important part of T2DM, but many feel that pancreatic beta cell function determines when those genetically at risk will develop $\mathrm{T}_{2} \mathrm{DM}^{34}$, beginning with defective first phase insulin secretion ${ }^{35}$. T2DM also involves a decrease in beta cell mass, due to factors such as glucose toxicity on the beta cell and lipotoxicity. The United Kingdom Prospective Diabetes Study (UKPDS) established that a decrease in HbA1c in T2DM decreases the incidence of microvascular complications ${ }^{36}$. Follow-up studies of this cohort showed that the same is true for macrovascular complications as well ${ }^{37,38}$. As in T1DM, hyperglycemia can cause increased oxidative stress, glycosylation of proteins such as LDL$\mathrm{C}$ (making them more atherogenic), decreased nitric oxide production, and increased coagulability, leading to endothelial injury and increased atherogenic risk ${ }^{34}$. In a metaanalysis of studies investigating the effect of improved glycemic control on macrovascular disease in both T1DM and T2DM, Stettler et al ${ }^{39}$ found that overall, improved glycemia decreased the incidence of macrovascular disease in T1DM and T2DM. In T2DM the effect was more modest, and stronger in younger individuals with shorter disease duration. In another study comparing complications prevalence in youth with T1DM to those with T2DM, the authors found that those with T2DM had increased prevalence of microalbuminuria and hypertension than those with T1DM, even though the youth with T2DM had shorter disease duration and lower $\mathrm{HbA} 1 \mathrm{c}^{40}$.

\section{Pathophysiology}

The metabolic consequences of obesity and insulin resistance in T2DM also lead to a specific atherogenic lipid profile, metabolic dyslipidemia ${ }^{41}$. Increased liver free fatty acid levels lead to increased triglyceride production, decreased LDL-C breakdown, decreased apolipoprotein B degradation, and increased very low density lipoprotein (VLDL) secretion ${ }^{42}$. Through the transfer of cholesterol esters and the action of hepatic lipase, increased VLDL results in increased triglycerides, decreased HDL-C, and the production of small, dense LDL particles. Increased free fatty acids may result from insulin resistance impairing the suppression of lipolysis, or from an adipocyte defect in the incorporation of free fatty acids into triglycerides. Increased free fatty acids also suppresses glucose uptake in muscle cells, further increasing insulin resistance ${ }^{42}$. In both type 1 and type 2 diabetics, poor glycemic control is associated with increased total cholesterol, LDL-C and triglycerides ${ }^{43}$.

The most recent pediatric CVD risk guidelines from the National Institutes of Health (NIH) National Heart, Lung, and Blood Institute (NHLBI) Expert Panel recommend universal lipid screening as well as more stringent cut-offs for normal triglyceride levels ${ }^{44}$. Moreover, it revised a previous scientific statement by the American Heart Association for children at high risk for CVD, which categorized T1DM as a high-risk condition and T2DM as moderate risk ${ }^{45}$. The new NHLBI guidelines state that based on increasing evidence of vascular disease in children with T2DM, both T1DM and T2DM should be included in the high risk category for risk stratification and management ${ }^{44}$.

Inflammation is also a key factor causing atherosclerosis ${ }^{46}$. Factors such as elevated and modified LDL-C cause endothelial injury, triggering an inflammatory response. The endothelium becomes more adhesive for leukocytes and platelets, increasing permeability and pro-coagulant properties. Cytokines, cellular adhesion molecules, and growth factors 
increase. Monocytes move to the endothelium, adhere to the surface, migrate into the subendothelium, and transform into macrophages. They take up lipoproteins, become foam cells, and initiate the fatty streak ${ }^{46}$, the beginning of the atherosclerotic lesion. Further injury continues to attract macrophages, mast cells, and activated T cells, and the lesion grows ${ }^{46-48}$. Insulin resistance is also felt to be involved in atherogenesis. Markers of insulin resistance are related to coronary atherosclerosis, independent of traditional risk factors ${ }^{49}$.

\section{Traditional and Novel Risk Factors for CVD in Youth}

The National Cholesterol Education Program (NCEP) identified the risk factors for early onset coronary heart disease in children and adolescents as elevated LDL-C, family history of early coronary heart disease, CVD or peripheral vascular disease, smoking, hypertension, HDL-C $<35 \mathrm{mg} / \mathrm{dl}$, obesity, physical inactivity, and diabetes ${ }^{50}$ As part of the SEARCH for Diabetes in Youth Study, Rodriguez et al compared the prevalence of CVD risk factors in children with T1DM and T2DM ${ }^{51}$, defining CVD risk factors according to the NCEP ATP III modified for age ${ }^{52}$. These authors defined CVD risk factors as HDL-C $<40 \mathrm{mg} / \mathrm{dl}$, ageand sex- specific waist circumference $>90 \%$ ile, systolic or diastolic blood pressure $>90 \%$ ile for age, sex, and height (or taking hypertension medication), and triglycerides $>110 \mathrm{mg} / \mathrm{dl}$. They found that $21 \%$ of diabetic children had at least two CVD risk factors- specifically $92 \%$ of children with T2DM and $14 \%$ of youth with T1DM ${ }^{51}$. Thus risk factors for CVD are clearly already present in youth with diabetes.

In a longitudinal study of fasting lipids in youth with T1DM, authors found that the prevalence of elevated LDL-C $(>100 \mathrm{mg} / \mathrm{dl}$ in diabetics compared to $>110 \mathrm{mg} / \mathrm{dl}$ in nondiabetics ${ }^{53}$ ) increased from $50 \%$ to $58 \%$ after a minimum of 3 years follow up. Furthermore, the changes in LDL-C, non-HDL-C, total cholesterol, and triglycerides were significantly related to changes in HbA1c. Changes in BMI-z score over time were significantly associated with changes in LDL-C and total cholesterol ${ }^{54}$. Non-HDL cholesterol has more recently been used to assess CVD risk, and is calculated as total cholesterol less HDL-C. It includes LDL-C, VLDL-C, and atherogenic apo-B containing lipoproteins. The Bogalusa Heart Study found non-HDL-C predicted carotid intimal-medial thickness in young adults ${ }^{55}$. The Pathological Determinants of Atherosclerosis in Youth study found non-HDL-C was strongly related to asymptomatic early subclinical coronary atherosclerosis ${ }^{56}$. In teens, non-HDL-C was strongly associated with the metabolic syndrome, with a non-HDL-C of $120 \mathrm{mg} / \mathrm{dl}$ and $145 \mathrm{mg} / \mathrm{dl}$ indicated high and very high risk of metabolic syndrome, respectively ${ }^{57}$.

Optimal blood pressure for diabetic children is < $90 \%$ ile for age, sex, and height, or < $130 / 80$ (whichever is lower), with $\geq 95 \%$ ile considered hypertension ${ }^{53}$. The SEARCH for Diabetes in Youth Study found that $73 \%$ of those with T2DM had elevated ( $290 \%$ ile) systolic or diastolic blood pressure, compared to $22 \%$ in $\mathrm{T}_{1} \mathrm{DM}^{51}$. These results were consistent with those of Eppens et al, who found that 36\% of adolescents with T2DM had hypertension, compared to $16 \%$ of those with $\mathrm{T}_{1 \mathrm{DM}}{ }^{40}$. Hypertension plays an important role in the development of atherosclerosis. Among children with T1DM followed over 4 years, investigators found that systolic blood pressure at baseline was a significant predictor of CIMT increase over time ${ }^{58}$. In youth with T2DM, Shah et al found that systolic blood pressure z-score was significantly associated with increased common carotid IMT ${ }^{59}$. Wadwa et al compared arterial stiffness measures in youth with T1DM and T2DM. They found significantly worse arterial stiffness in those with T2DM, and that this difference was largely determined by higher blood pressures and increased central adiposity in $\mathrm{T}_{2} \mathrm{DM}^{60}$. Prospective studies will be needed to determine whether hypertension plays a larger role in increasing CVD risk in childhood T2DM compared to its effects in T1DM. 
There are also several non-traditional CVD risk factors currently being used in research settings. Lipoprotein subclass particle analysis by NMR spectroscopy can yield important information about CVD risk, not evident from traditional lipid analysis ${ }^{61}$. Obesity and insulin resistance can lead to a highly atherogenic dyslipidemia pattern characterized by decreased HDL-C, increased TG, and increased small subspecies of LDL-particles ${ }^{41}$. In adults, small LDL ${ }^{62}$, large VLDL, and small $\mathrm{HDL}^{63}$ are associated with increased CVD risk. Smaller HDL ${ }^{64}$, larger VLDL and small LDL ${ }^{65}$ particles correlate with obesity and insulin resistance in children. Although small subspecies of LDL-particles not measured in routine pediatric clinical care, a recent study found that in white overweight youth, TG/HDL-C $\geq 3$ and a non-HDL-C of $\geq 120 \mathrm{mg} / \mathrm{dl}$ each predicted increased small atherogenic LDL-particles. In black overweight youth, these cut-offs were $\geq 2.5$ for TG/HDL and $\geq 145 \mathrm{mg} / \mathrm{dl}$ for nonHDL-C ${ }^{66}$. These calculated measures based on a standard lipid panel hold great promise to identify children at increased CVD risk in clinical practice.

Inflammatory markers are also being measured by investigators. The liver produces highsensitivity C-reactive protein (hs-CRP), which in adults is an independent predictor of CVD events ${ }^{67}$, and is related to insulin sensitivity in the metabolic syndrome ${ }^{68}$. In children, hsCRP is significantly elevated in obese compared to nonobese adolescents, but its association with insulin resistance is unclear ${ }^{69,70}$. Adipose tissue, now recognized as an endocrine organ, produces interleukin-6 (IL-6), which has also been associated with CVD in adults 67 and with obesity in children ${ }^{70}$. Both CRP and IL-6 were predictive of T2DM development in adult women of the Women's Health Study ${ }^{71}$, suggesting that inflammation may play a role in diabetes development. Macrophages produce cytokines such as tumor necrosis factor alpha (TNF-a, also produced by adipose tissue), which act as mediators of T cell activation and foam cell formation ${ }^{46}$, and of the acute phase response ${ }^{72}$. In adults ${ }^{73,74}$ and children ${ }^{75}$, TNF-a receptor II (TNFR2) has been found to be higher in obese subjects with impaired glucose tolerance, IR, and diabetes. Finally, the endothelium is also involved in inflammation, and produces cellular adhesion molecules such as intercellular adhesion molecule 1 (ICAM-1), which provide evidence of endothelial cell activation and dysfunction ${ }^{76,77}$. Endothelial dysfunction, as measured by ICAM-1, was found to be predictive of T2DM in women, independent of obesity or CRP ${ }^{76}$, and was elevated in obese compared to nonobese children ${ }^{78}$. Plasminogen activator inhibitor-1 (PAI-1) is an inhibitor of fibrinolysis, and is secreted by several sources, including adipose tissue and vascular endothelium. It is increased in the inflammatory state, and associated with increased CVD risk. ${ }^{79}$ These markers may provide incremental information in assessing CVD risk in obese children, but have been limited thus far to the research setting.

Adipocytes also produce adipokines which have inflammatory and/or atherogenic effects. Adiponectin and leptin have been implicated in the physiology of obesity and have receptors present throughout the cardiovascular system ${ }^{80}$. Adiponectin has anti-inflammatory and anti-atherogenic effects. ${ }^{81,82}$ In adults, hypoadiponectinemia has been associated with insulin resistance, the progression of T2DM ${ }^{83}$, and coronary artery disease ${ }^{84}$, including among type 2 diabetics ${ }^{85}$. In children, adiponectin is decreased with obesity ${ }^{70}$, insulin resistance ${ }^{86}$, and T2DM ${ }^{87}$. The mechanism of adiponectin's seemingly protective effect is unknown. Our group showed lower adiponectin levels and a more atherogenic lipoprotein profile, both associated with increased insulin resistance, in obese compared to lean adolescents. Adiponectin was associated inversely with small LDL-P and small HDL-P, and positively with HDL-P size in obese adolescents, even after adjusting for BMI and insulin resistance. ${ }^{88}$ In a study of obese children, Beauloye et al found that adiponectin, more than conventional CVD risk factors, was an independent determinant of CIMT ${ }^{89}$. Leptin acts at the hypothalamus to suppress appetite and regulate weight, ${ }^{90}$ and has proinflammatory and proatherogenic effects ${ }^{91}$. It is positively associated with percent body fat, and obese individuals may have a degree of leptin resistance ${ }^{92}$. In a prospective treatment trial to 
prevent ischemic heart disease, elevated plasma leptin levels predicted acute CVD events ${ }^{93}$. Leptin is also associated with intimal-medial thickness of the common carotid artery in normal weight and obese individuals ${ }^{94}$.

Vitamin D deficiency (VDD) may be another non-traditional risk factor for CVD among youth with diabetes. Adults with T2DM have a higher prevalence of VDD than controls, and those with VDD had increased CIMT ${ }^{95}$. Among adult diabetics, VDD was associated with the presence of nephropathy as well ${ }^{96}$. In a recent study of adolescents with T1DM, VDD was associated with diabetic retinopathy, independent of diabetes duration and $\mathrm{HbA} 1 \mathrm{c}^{97}$. Further research is needed to establish causation.

\section{Vascular Imaging Studies}

One of the obvious limitations to studying CVD risk in children is that the final outcome has not yet occurred. Therefore, valid surrogate endpoints are crucial. Noninvasive vascular imaging techniques, developed to investigate CVD risk in adults, are particularly suited to a pediatric population, given that they can detect early disease and that they are non-invasive. One of these techniques is carotid intimal medial thickness (CIMT), measured by Doppler ultrasound to evaluate subclinical atherosclerosis ${ }^{98}$. CIMT is established as an independent predictor of CVD risk in adults ${ }^{99,100}$, and increased CIMT is a structural marker of early atherosclerosis. CIMT is higher in type 2 diabetic adults than healthy controls ${ }^{101}$, and CIMT has been found to respond to treatment of T2DM ${ }^{102,103}$. Several studies have found that obese children have significantly increased CIMT than controls $104-106$. In a study of 129 adolescents and young adults with T2DM, Shah et al found that higher HbA1c and longer diabetes duration was associated with increased CIMT. For each $1 \%$ increase in $\mathrm{HbA} 1 \mathrm{c}$ or 1 year in diabetes duration, there was a $30 \%$ increased odds of thicker CIMT. Moreover, among the T2DM cohort, males had worse CIMT $^{59}$ than females.

CIMT studies in youth with T1DM have had conflicting results, with some showing increased CIMT in children with T1DM ${ }^{107-109}$, and others showing no difference ${ }^{110-112}$. Krantz et al not only found that children with T1DM had increased CIMT compared to controls, but also that CIMT was higher in those with T1DM and a complication such as retinopathy, hypertension, and/or microalbuminuria ${ }^{109}$. In a large study of more than 300 children with T1DM in Norway, investigators found that boys with T1DM, but not girls, had a statistically significant increase in CIMT ${ }^{113}$. In a study of 270 German children with T1DM, boys had significantly higher bilateral mean CIMT compared to females, and the authors developed sex-specific CIMT percentiles. CIMT was related to diabetes duration and pulse pressure in males, and with LDL-C, HbA1c, and diabetes duration in females ${ }^{114}$. However, longitudinal studies of CIMT in youth with diabetes are very limited. In children with T1DM, Dalla Pozza et al found that CIMT increased significantly over 4 years, and that the increase was predicted by baseline BMI z-score, diabetes duration, and systolic blood pressure $^{58}$.

Another vascular technique, flow-mediated dilation (FMD) of the brachial artery, is also measured by Doppler ultrasound ${ }^{115-117}$. FMD is measured after transient vascular occlusion, and is thought to be a measure of nitric oxide bioavailability, and thus endothelial function. FMD has been used to show that severely obese children have reduced endothelial function, compared to nonobese controls ${ }^{118}$, which normalized after an exercise therapy intervention ${ }^{119}$. Several studies have found that obese children have significantly worse FMD $104,105,119$. Children with T1DM have impaired endothelial function compared to controls, within the first decade of diagnosis ${ }^{110,120}$, and even in prepubertal children ${ }^{112}$. A recent study by Battelino et al found that 33\% of children and adolescents with T1DM had endothelial dysfunction, as defined by endothelium dependent dilation of $3.3 \%$ or less ${ }^{121}$, based on FMD measurements in healthy children by Jarvisalo et al ${ }^{116}$. This endothelial 
dysfunction was independently negatively associated with HbA1c. Interestingly, it was also independently associated with the presence of a polymorphism of the endothelial nitric oxide synthase gene ${ }^{121}$.

Arterial stiffness can be assessed using aortic PWV and pulse wave analysis (PWA) to obtain central pulse pressure (CPP). PWV measures arterial stiffness--a stiffer aorta conducts the pulse wave more quickly. It is a marker of $\mathrm{CVD}^{122}$ and is increased in obesity $^{123}$. Higher mean arterial BP increases PWV, but other factors are also operative. As the aorta stiffens, its ability to cushion stroke volume is diminished and the pulsatile energy of left ventricular contraction passes onto peripheral tissues. Increased pulsatile forces at smaller vessels contribute to vascular remodeling and hypertrophy, and target organ damage. PWA estimates reflected wave effects on central circulation. Increasing reflected wave magnitude affects ventricular systole and contributes to LV hypertrophy and coronary ischemia.

Arterial stiffness measures have been used in children to identify evidence of early CVD. In a pilot study, Gungor et al ${ }^{124}$ found no difference in CIMT between 20 T2DM adolescents, 20 obese nondiabetics, and 22 lean controls, but did find differences in arterial stiffness. In "The Search for Diabetes in Youth" study ${ }^{60} \mathrm{PWV}$ was higher in T2DM $(6.4 \pm 1.3 \mathrm{~m} / \mathrm{s}) \mathrm{vs}$ T1DM $(5.3 \pm 0.8 \mathrm{~m} / \mathrm{s}), \mathrm{p}<0.0001$, suggestive of increased CVD risk in T2DM. Another group used T1DM data from the same study, and found that children with T1DM had increased PWV compared to controls, which was especially true in males. Also, traditional CVD risk factors such as blood pressure, BMI, and cholesterol correlated with PWV ${ }^{125}$. Collins et al found differences in arterial compliance already present in normotensive adolescent subjects $^{126}$. Age-, height- and sex- specific reference values for PWV in children have been published as well ${ }^{127}$. Recent findings by Shah et al show racial differences in PWV. These investigators found that African American adolescents and young adults with T2DM had increased arterial stiffness compared to Caucasians with T2DM, and that this stiffness was mediated by different CVD risk factors in the two races ${ }^{128}$.

Coronary artery calcification (CAC) measurement by electron beam computed tomography (CT) is another surrogate measure used to identify coronary atherosclerosis ${ }^{98}$. Studies measuring CAC in adolescents and young adults with T1DM, have had variable results, possibly due to the age of the youth studied as CAC develops late in the atherosclerotic process. Gunczler et al studied Hispanic children 3-16 years old with T1DM, and found no evidence of CAC in either diabetics or controls ${ }^{129}$. However, Starkman et al studied youth 17-28 years old with T1DM, and found that $10.9 \%$ had $\mathrm{CAC}^{130}$. Use of this technique in the pediatric population should be limited because of the radiation exposure involved and low likelihood of positive studies.

Left ventricular (LV) mass, measured by echocardiography, is associated with pediatric obesity $^{131}$, and is a predictor of cardiovascular events in adults ${ }^{132,133}$. Childhood obesity is associated with increased cardiac mass as an adult ${ }^{134}$, and increased childhood weight may increase adult LV mass beyond expected based on growth alone ${ }^{135}$. Recently, Crowley et al showed that LV mass indexed for height was higher in this generation of children (not limited to obese) compared to a generation ago, due in part to increased BMI over time ${ }^{136}$. Furthermore, age-specific reference intervals for LV mass index in children have been published ${ }^{137}$. However, in adolescents with T1DM, Parikh et al did not find an increase in LV mass ${ }^{111}$.

In recent novel studies, retinal photography has been used to measure retinal vascular geometry among adolescents with T1DM to predict microvascular complications. BenitezAguirre et al performed prospective studies in adolescents and young adults with T1DM, 
and found that measures of retinal vascular geometry independently predicted diabetic retinopathy ${ }^{138}$ and nephropathy ${ }^{139}$ among type 1 diabetics 12 to 20 years old. Further studies will be needed to confirm these results.

\section{Conclusion}

With rates of T1DM and T2DM in children rising, it is crucial that physicians identify children at the greatest CVD risk and implement prevention and treatment measures during childhood. Many have been reluctant to put children going through the growth and puberty associated with adolescence on pharmacologic therapy. However, the alternative may not be very reassuring. Knowing that atherosclerosis begins in youth, and with copious research illustrating increased prevalence of CVD risk factors (both traditional and nontraditional) during childhood, these findings need to be translated into clinical practice. Research is rapidly moving forward, trying to identify which biomarkers and/or vascular imaging techniques are the best surrogate markers for CVD risk. Longitudinal clinical intervention trials using these surrogate markers are sorely needed in pediatrics to establish the best ways to slow the progression of atherosclerosis in children with diabetes. In order to prevent a generation of youth from developing cardiovascular events during their 30's and 40's, pediatricians will need to be able to identify those diabetic children at the highest CVD risk, and initiate aggressive prevention and treatment.

\section{References}

Papers of particular interest, published recently, have been highlighted as:

- Of importance

•• Of major importance

1. Incidence and trends of childhood Type 1 diabetes worldwide 1990-1999. Diabet Med. 2006; 23(8): 857-66. [PubMed: 16911623]

2. Vehik K, Hamman RF, Lezotte D, Norris JM, Klingensmith G, Bloch C, et al. Increasing incidence of type 1 diabetes in 0- to 17-year-old Colorado youth. Diabetes Care. 2007; 30(3):503-9. [PubMed: 17327312]

3. EURODIAB ACE Study Group. Variation and trends in incidence of childhood diabetes in Europe. Lancet. 2000; 355(9207):873-6. [PubMed: 10752702]

4. Ogden CL, Carroll MD, Curtin LR, McDowell MA, Tabak CJ, Flegal KM, et al. Prevalence of overweight and obesity in the United States, 1999-2004. Jama. 2006; 295(13):1549-55. [PubMed: 16595758]

5. Pinhas-Hamiel O, Dolan LM, Daniels SR, Standiford D, Khoury PR, Zeitler P. Increased incidence of non-insulin-dependent diabetes mellitus among adolescents [see comments]. Comment in: J Pediatr 1996 May;128(5 Pt 1):591. Journal of Pediatrics. 1996; 128(5 Pt 1):608-15. [PubMed: 8627431]

6. Type 2 diabetes in children and adolescents. American Diabetes Association. Diabetes Care. 2000; 23(3):381-9. [PubMed: 10868870]

7. Liese AD, D'Agostino RB Jr, Hamman RF, Kilgo PD, Lawrence JM, Liu LL, et al. The burden of diabetes mellitus among US youth: prevalence estimates from the SEARCH for Diabetes in Youth Study. Pediatrics. 2006; 118(4):1510-8. [PubMed: 17015542]

8. American Academy of Pediatrics. National Cholesterol Education Program: Report of the Expert Panel on Blood Cholesterol Levels in Children and Adolescents. Pediatrics. 1992; 89(3 Pt 2):52584. [PubMed: 1538956]

9. Juutilainen A, Lehto S, Ronnemaa T, Pyorala K, Laakso M. Type 2 diabetes as a "coronary heart disease equivalent": an 18-year prospective population-based study in Finnish subjects. Diabetes Care. 2005; 28(12):2901-7. [PubMed: 16306552] 
10. Strong JP, Malcom GT, McMahan CA, Tracy RE, Newman WP 3rd, Herderick EE, et al. Prevalence and extent of atherosclerosis in adolescents and young adults: implications for prevention from the Pathobiological Determinants of Atherosclerosis in Youth Study. Jama. 1999; 281(8):727-35. [PubMed: 10052443]

11. McGill HC Jr, McMahan CA, Herderick EE, Zieske AW, Malcom GT, Tracy RE, et al. Obesity accelerates the progression of coronary atherosclerosis in young men. Circulation. 2002; 105(23): 2712-8. [PubMed: 12057983]

12. Berenson GS, Srinivasan SR, Bao W, Newman WP 3rd, Tracy RE, Wattigney WA. Association between multiple cardiovascular risk factors and atherosclerosis in children and young adults. The Bogalusa Heart Study. N Engl J Med. 1998; 338(23):1650-6. [PubMed: 9614255]

13. Freedman DS, Dietz WH, Tang R, Mensah GA, Bond MG, Urbina EM, et al. The relation of obesity throughout life to carotid intima-media thickness in adulthood: the Bogalusa Heart Study. Int J Obes Relat Metab Disord. 2004; 28(1):159-66. [PubMed: 14581934]

14. Mahoney LT, Burns TL, Stanford W, Thompson BH, Witt JD, Rost CA, et al. Coronary risk factors measured in childhood and young adult life are associated with coronary artery calcification in young adults: the Muscatine Study. J Am Coll Cardiol. 1996; 27(2):277-84. [PubMed: 8557894]

15. Raitakari OT, Juonala M, Kahonen M, Taittonen L, Laitinen T, Maki-Torkko N, et al. Cardiovascular risk factors in childhood and carotid artery intima-media thickness in adulthood: the Cardiovascular Risk in Young Finns Study. Jama. 2003; 290(17):2277-83. [PubMed: 14600186]

16. Krolewski AS, Kosinski EJ, Warram JH, Leland OS, Busick EJ, Asmal AC, et al. Magnitude and determinants of coronary artery disease in juvenile-onset, insulin-dependent diabetes mellitus. Am J Cardiol. 1987; 59(8):750-5. [PubMed: 3825934]

17. The Diabetes Control and Complications Trial Research Group. The effect of intensive treatment of diabetes on the development and progression of long-term complications in insulin-dependent diabetes mellitus. N Engl J Med. 1993; 329(14):977-86. [PubMed: 8366922]

18. Nathan DM, Cleary PA, Backlund JY, Genuth SM, Lachin JM, Orchard TJ, et al. Intensive diabetes treatment and cardiovascular disease in patients with type 1 diabetes. N Engl J Med. 2005; 353(25):2643-53. [PubMed: 16371630]

19. Nathan DM, Lachin J, Cleary P, Orchard T, Brillon DJ, Backlund JY, et al. Intensive diabetes therapy and carotid intima-media thickness in type 1 diabetes mellitus. N Engl J Med. 2003; 348(23):2294-303. [PubMed: 12788993]

20. Schmidt AM, Yan SD, Wautier JL, Stern D. Activation of receptor for advanced glycation end products: a mechanism for chronic vascular dysfunction in diabetic vasculopathy and atherosclerosis. Circ Res. 1999; 84(5):489-97. [PubMed: 10082470]

21. Libby P, Plutzky J. Diabetic macrovascular disease: the glucose paradox? Circulation. 2002; 106(22):2760-3. [PubMed: 12450998]

22. Snell-Bergeon JK, Hokanson JE, Jensen L, MacKenzie T, Kinney G, Dabelea D, et al. Progression of coronary artery calcification in type 1 diabetes: the importance of glycemic control. Diabetes Care. 2003; 26(10):2923-8. [PubMed: 14514603]

23. Shamir R, Kassis H, Kaplan M, Naveh T, Shehadeh N. Glycemic control in adolescents with type 1 diabetes mellitus improves lipid serum levels and oxidative stress. Pediatr Diabetes. 2008; 9(2): 104-9. [PubMed: 18221422]

24. Shen X, Zheng S, Thongboonkerd V, Xu M, Pierce WM Jr, Klein JB, et al. Cardiac mitochondrial damage and biogenesis in a chronic model of type 1 diabetes. Am J Physiol Endocrinol Metab. 2004; 287(5):E896-905. [PubMed: 15280150]

*25. Schauer IE, Snell-Bergeon JK, Bergman BC, Maahs DM, Kretowski A, Eckel RH, et al. Insulin resistance, defective insulin-mediated fatty acid suppression, and coronary artery calcification in subjects with and without type 1 diabetes: The CACTI study. Diabetes. 2011; 60(1):306-14. This study used hyperinsulinemic euglycemic clamp studies to illustrate increased insulin resistance among Type 1 diabetes which predicted increased coronary artery calcification. [PubMed: 20978091] 
*26. Nadeau KJ, Regensteiner JG, Bauer TA, Brown MS, Dorosz JL, Hull A, et al. Insulin resistance in adolescents with type 1 diabetes and its relationship to cardiovascular function. J Clin Endocrinol Metab. 2010; 95(2):513-21. This study investigated the effected of insulin resistance in children with type 1 diabetes. [PubMed: 19915016]

27. Suys BE, Katier N, Rooman RP, Matthys D, Op De Beeck L, Du Caju MV, et al. Female children and adolescents with type 1 diabetes have more pronounced early echocardiographic signs of diabetic cardiomyopathy. Diabetes Care. 2004; 27(8):1947-53. [PubMed: 15277422]

28. Moss SE, Klein R, Klein BE. Cause-specific mortality in a population-based study of diabetes. Am J Public Health. 1991; 81(9):1158-62. [PubMed: 1951827]

29. Stamler J, Vaccaro O, Neaton JD, Wentworth D. Diabetes, other risk factors, and 12-yr cardiovascular mortality for men screened in the Multiple Risk Factor Intervention Trial. Diabetes Care. 1993; 16(2):434-44. [PubMed: 8432214]

30. Reaven GM. Banting lecture 1988. Role of insulin resistance in human disease. Diabetes. 1988; 37(12):1595-607. [PubMed: 3056758]

31. Boyd GS, Koenigsberg J, Falkner B, Gidding S, Hassink S. Effect of obesity and high blood pressure on plasma lipid levels in children and adolescents. Pediatrics. 2005; 116(2):442-6. [PubMed: 16061601]

32. Invitti C, Guzzaloni G, Gilardini L, Morabito F, Viberti G. Prevalence and concomitants of glucose intolerance in European obese children and adolescents. Diabetes Care. 2003; 26(1):118-24. [PubMed: 12502667]

33. Davis CL, Flickinger B, Moore D, Bassali R, Domel Baxter S, Yin Z, et al. Prevalence of cardiovascular risk factors in schoolchildren in a rural Georgia community. American Journal of the Medical Sciences. 2005; 330(2):53-9. [PubMed: 16103784]

34. Gerich JE. Clinical significance, pathogenesis, and management of postprandial hyperglycemia. Arch Intern Med. 2003; 163(11):1306-16. [PubMed: 12796066]

35. Leahy JL. Pathogenesis of Type 2 Diabetes Mellitus. Archives of Medical Research Current Trends in Diabetes. 2005; 36(3):197-209.

36. UK Prospective Diabetes Study (UKPDS) Group. Intensive blood-glucose control with sulphonylureas or insulin compared with conventional treatment and risk of complications in patients with type 2 diabetes (UKPDS 33). Lancet. 1998; 352(9131):837-53. [PubMed: 9742976]

37. Holman RR, Paul SK, Bethel MA, Matthews DR, Neil HA. 10-year follow-up of intensive glucose control in type 2 diabetes. N Engl J Med. 2008; 359(15):1577-89. [PubMed: 18784090]

38. Stratton IM, Adler AI, Neil HA, Matthews DR, Manley SE, Cull CA, et al. Association of glycaemia with macrovascular and microvascular complications of type 2 diabetes (UKPDS 35): prospective observational study. Bmj. 2000; 321(7258):405-12. [PubMed: 10938048]

39. Stettler C, Allemann S, Juni P, Cull CA, Holman RR, Egger M, et al. Glycemic control and macrovascular disease in types 1 and 2 diabetes mellitus: Meta-analysis of randomized trials. Am Heart J. 2006; 152(1):27-38. [PubMed: 16824829]

40. Eppens MC, Craig ME, Cusumano J, Hing S, Chan AK, Howard NJ, et al. Prevalence of diabetes complications in adolescents with type 2 compared with type 1 diabetes. Diabetes Care. 2006; 29(6):1300-6. [PubMed: 16732012]

41. Third Report of the National Cholesterol Education Program (NCEP) Expert Panel on Detection, Evaluation, and Treatment of High Blood Cholesterol in Adults (Adult Treatment Panel III) final report. Circulation. 2002; 106(25):3143-421. [PubMed: 12485966]

42. Kwiterovich PO Jr. The metabolic pathways of high-density lipoprotein, low-density lipoprotein, and triglycerides: a current review. Am J Cardiol. 2000; 86(12A):5L-10L.

43. Petitti DB, Imperatore G, Palla SL, Daniels SR, Dolan LM, Kershnar AK, et al. Serum lipids and glucose control: the SEARCH for Diabetes in Youth study. Arch Pediatr Adolesc Med. 2007; 161(2):159-65. [PubMed: 17283301]

**44. Expert panel on integrated guidelines for cardiovascular health and risk reduction in children and adolescents: summary report. Pediatrics. 2011; 128(Suppl 5):S213-56. These guidelines by the NHLBI recommend more aggressive lipid cut-offs for children, and recognize both type 1 and type 2 diabetes as conditions associated with accelerated atherosclerosis. [PubMed: 22084329] 
45. Kavey RE, Allada V, Daniels SR, Hayman LL, McCrindle BW, Newburger JW, et al. Cardiovascular risk reduction in high-risk pediatric patients: a scientific statement from the American Heart Association Expert Panel on Population and Prevention Science; the Councils on Cardiovascular Disease in the Young, Epidemiology and Prevention, Nutrition, Physical Activity and Metabolism, High Blood Pressure Research, Cardiovascular Nursing, and the Kidney in Heart Disease; and the Interdisciplinary Working Group on Quality of Care and Outcomes Research: endorsed by the American Academy of Pediatrics. Circulation. 2006; 114(24):2710-38. [PubMed: 17130340]

46. Ross R. Atherosclerosis--an inflammatory disease. N Engl J Med. 1999; 340(2):115-26. [PubMed: 9887164]

47. Pearson TA, Mensah GA, Alexander RW, Anderson JL, Cannon RO 3rd, Criqui M, et al. Markers of inflammation and cardiovascular disease: application to clinical and public health practice: A statement for healthcare professionals from the Centers for Disease Control and Prevention and the American Heart Association. Circulation. 2003; 107(3):499-511. [PubMed: 12551878]

48. Miller J, Rosenbloom A, Silverstein J. Childhood obesity. J Clin Endocrinol Metab. 2004; 89(9): 4211-8. [PubMed: 15356008]

49. Reilly MP, Wolfe ML, Rhodes T, Girman C, Mehta N, Rader DJ. Measures of insulin resistance add incremental value to the clinical diagnosis of metabolic syndrome in association with coronary atherosclerosis. Circulation. 2004; 110(7):803-9. [PubMed: 15289378]

50. National Cholesterol Education Program (NCEP): highlights of the report of the Expert Panel on Blood Cholesterol Levels in Children and Adolescents. Pediatrics. 1992; 89(3):495-501. [PubMed: 1741227]

51. Rodriguez BL, Fujimoto WY, Mayer-Davis EJ, Imperatore G, Williams DE, Bell RA, et al. Prevalence of cardiovascular disease risk factors in U.S. children and adolescents with diabetes: the SEARCH for diabetes in youth study. Diabetes Care. 2006; 29(8):1891-6. [PubMed: 16873798]

52. Cook S, Weitzman M, Auinger P, Nguyen M, Dietz WH. Prevalence of a metabolic syndrome phenotype in adolescents: findings from the third National Health and Nutrition Examination Survey, 1988-1994. Arch Pediatr Adolesc Med. 2003; 157(8):821-7. [PubMed: 12912790]

53. Standards of medical care in diabetes--2011. Diabetes Care. 2011; 34(Suppl 1):S11-61. [PubMed: 21193625]

54. Reh CM, Mittelman SD, Wee CP, Shah AC, Kaufman FR, Wood JR. A longitudinal assessment of lipids in youth with type 1 diabetes. Pediatr Diabetes. 2011; 12(4 Pt 2):365-71. [PubMed: 21392191]

55. Frontini MG, Srinivasan SR, Xu JH, Tang R, Bond MG, Berenson G. Utility of non-high-density lipoprotein cholesterol versus other lipoprotein measures in detecting subclinical atherosclerosis in young adults (The Bogalusa Heart Study). Am J Cardiol. 2007; 100(1):64-8. [PubMed: 17599442]

56. Rainwater DL, McMahan CA, Malcom GT, Scheer WD, Roheim PS, McGill HC Jr, et al. Lipid and apolipoprotein predictors of atherosclerosis in youth: apolipoprotein concentrations do not materially improve prediction of arterial lesions in PDAY subjects. The PDAY Research Group. Arterioscler Thromb Vasc Biol. 1999; 19(3):753-61. [PubMed: 10073983]

*57. Li C, Ford ES, McBride PE, Kwiterovich PO, McCrindle BW, Gidding SS. Non-high-density lipoprotein cholesterol concentration is associated with the metabolic syndrome among US youth aged 12-19 years. J Pediatr. 2011; 158(2):201-7. This paper establishes non-HDL cut-offs for youth at increased risk for metabolic syndrome. [PubMed: 20828715]

*58. Dalla, Pozza R.; Beyerlein, A.; Thilmany, C.; Weissenbacher, C.; Netz, H.; Schmidt, H., et al. The effect of cardiovascular risk factors on the longitudinal evolution of the carotid intima medial thickness in children with type 1 diabetes mellitus. Cardiovasc Diabetol. 2011; 10:53. One of the first longitudinal studies of progression of CIMT over time in youth with diabetes. [PubMed: 21679428]

59. Shah AS, Dolan LM, Kimball TR, Gao Z, Khoury PR, Daniels SR, et al. Influence of duration of diabetes, glycemic control, and traditional cardiovascular risk factors on early atherosclerotic vascular changes in adolescents and young adults with type 2 diabetes mellitus. J Clin Endocrinol Metab. 2009; 94(10):3740-5. [PubMed: 19723759] 
*60. Wadwa RP, Urbina EM, Anderson AM, Hamman RF, Dolan LM, Rodriguez BL, et al. Measures of arterial stiffness in youth with type 1 and type 2 diabetes: the SEARCH for diabetes in youth study. Diabetes Care. 2010; 33(4):881-6. This manuscript compares arterial stiffness in youth with type 1 and type 2 diabetes. [PubMed: 20067960]

61. Garvey WT, Kwon S, Zheng D, Shaughnessy S, Wallace P, Hutto A, et al. Effects of insulin resistance and type 2 diabetes on lipoprotein subclass particle size and concentration determined by nuclear magnetic resonance. Diabetes. 2003; 52(2):453-62. [PubMed: 12540621]

62. Austin MA, King MC, Vranizan KM, Krauss RM. Atherogenic lipoprotein phenotype. A proposed genetic marker for coronary heart disease risk. Circulation. 1990; 82(2):495-506. [PubMed: 2372896]

63. Freedman DS, Otvos JD, Jeyarajah EJ, Barboriak JJ, Anderson AJ, Walker JA. Relation of lipoprotein subclasses as measured by proton nuclear magnetic resonance spectroscopy to coronary artery disease. Arterioscler Thromb Vasc Biol. 1998; 18(7):1046-53. [PubMed: 9672064]

64. Perez-Mendez O, Torres-Tamayo M, Posadas-Romero C, Vidaure Garces V, Carreon-Torres E, Mendoza-Perez E, et al. Abnormal HDL subclasses distribution in overweight children with insulin resistance or type 2 diabetes mellitus. Clin Chim Acta. 2007; 376(1-2):17-22. [PubMed: 16934792]

65. Freedman DS, Bowman BA, Otvos JD, Srinivasan SR, Berenson GS. Levels and correlates of LDL and VLDL particle sizes among children: the Bogalusa heart study. Atherosclerosis. 2000; 152(2): 441-9. [PubMed: 10998473]

*66. Burns SF, Lee SJ, Arslanian SA. Surrogate Lipid Markers for Small Dense Low-Density Lipoprotein Particles in Overweight Youth. J Pediatr. 2012 This paper identifies calculated indices predictive of increased small dense LDL, using a standard lipid panel. These indices may be useful in clinic al practice to identify children with increased CVD risk.

67. Ridker PM, Hennekens CH, Buring JE, Rifai N. C-reactive protein and other markers of inflammation in the prediction of cardiovascular disease in women. N Engl J Med. 2000; 342(12): 836-43. [PubMed: 10733371]

68. Festa A, D'Agostino R Jr, Howard G, Mykkanen L, Tracy RP, Haffner SM. Chronic subclinical inflammation as part of the insulin resistance syndrome: the Insulin Resistance Atherosclerosis Study (IRAS). Circulation. 2000; 102(1):42-7. [PubMed: 10880413]

69. Mangge H, Schauenstein K, Stroedter L, Griesl A, Maerz W, Borkenstein M. Low grade inflammation in juvenile obesity and type 1 diabetes associated with early signs of atherosclerosis. Exp Clin Endocrinol Diabetes. 2004; 112(7):378-82. [PubMed: 15239023]

70. Weiss R, Dziura J, Burgert TS, Tamborlane WV, Taksali SE, Yeckel CW, et al. Obesity and the metabolic syndrome in children and adolescents. N Engl J Med. 2004; 350(23):2362-74. [PubMed: 15175438]

71. Pradhan AD, Manson JE, Rifai N, Buring JE, Ridker PM. C-reactive protein, interleukin 6, and risk of developing type 2 diabetes mellitus. Jama. 2001; 286(3):327-34. [PubMed: 11466099]

72. Nesto R. C-reactive protein, its role in inflammation, Type 2 diabetes and cardiovascular disease, and the effects of insulin-sensitizing treatment with thiazolidinediones. Diabet Med. 2004; 21(8): 810-7. [PubMed: 15270782]

73. Bullo M, Garcia-Lorda P, Megias I, Salas-Salvado J. Systemic inflammation, adipose tissue tumor necrosis factor, and leptin expression. Obes Res. 2003; 11(4):525-31. [PubMed: 12690081]

74. Dzienis-Straczkowska S, Straczkowski M, Szelachowska M, Stepien A, Kowalska I, Kinalska I. Soluble tumor necrosis factor-alpha receptors in young obese subjects with normal and impaired glucose tolerance. Diabetes Care. 2003; 26(3):875-80. [PubMed: 12610052]

75. Gupta A, Ten S, Anhalt H. Serum levels of soluble tumor necrosis factor-alpha receptor 2 are linked to insulin resistance and glucose intolerance in children. J Pediatr Endocrinol Metab. 2005; 18(1):75-82. [PubMed: 15679072]

76. Meigs JB, Hu FB, Rifai N, Manson JE. Biomarkers of endothelial dysfunction and risk of type 2 diabetes mellitus. Jama. 2004; 291(16):1978-86. [PubMed: 15113816]

77. Miller J, Silverstein J. Cardiovascular risk factors in childhood diabetes. The Endocrinologist. 2003; 13(5):394- 407. 
78. Desideri G, De Simone M, Iughetti L, Rosato T, Iezzi ML, Marinucci MC, et al. Early activation of vascular endothelial cells and platelets in obese children. Journal of Clinical Endocrinology \& Metabolism. 2005; 90(6):3145-52. [PubMed: 15755862]

79. Vaughan DE. PAI-1 and atherothrombosis. J Thromb Haemost. 2005; 3(8):1879-83. [PubMed: 16102055]

80. Kougias P, Chai H, Lin PH, Yao Q, Lumsden AB, Chen C. Effects of adipocyte-derived cytokines on endothelial functions: implication of vascular disease. J Surg Res. 2005; 126(1):121-9. [PubMed: 15916985]

81. Goldstein BJ, Scalia R. Adiponectin: A novel adipokine linking adipocytes and vascular function. J Clin Endocrinol Metab. 2004; 89(6):2563-8. [PubMed: 15181024]

82. Antoniades C, Antonopoulos AS, Tousoulis D, Stefanadis C. Adiponectin: from obesity to cardiovascular disease. Obes Rev. 2009; 10(3):269-79. [PubMed: 19389061]

83. Spranger J, Kroke A, Mohlig M, Bergmann MM, Ristow M, Boeing H, et al. Adiponectin and protection against type 2 diabetes mellitus. Lancet. 2003; 361(9353):226-8. [PubMed: 12547549]

84. Ouchi N, Kihara S, Arita Y, Maeda K, Kuriyama H, Okamoto Y, et al. Novel modulator for endothelial adhesion molecules: adipocyte-derived plasma protein adiponectin. Circulation. 1999; 100(25):2473-6. [PubMed: 10604883]

85. Hotta K, Funahashi T, Arita Y, Takahashi M, Matsuda M, Okamoto Y, et al. Plasma concentrations of a novel, adipose-specific protein, adiponectin, in type 2 diabetic patients. Arterioscler Thromb Vasc Biol. 2000; 20(6):1595-9. [PubMed: 10845877]

86. Weiss R, Taksali SE, Dufour S, Yeckel CW, Papademetris X, Cline G, et al. The "obese insulinsensitive" adolescent: importance of adiponectin and lipid partitioning. J Clin Endocrinol Metab. 2005; 90(6):3731-7. [PubMed: 15797955]

87. Morales A, Wasserfall C, Brusko T, Carter C, Schatz D, Silverstein J, et al. Adiponectin and leptin concentrations may aid in discriminating disease forms in children and adolescents with type 1 and type 2 diabetes. Diabetes Care. 2004; 27(8):2010-4. [PubMed: 15277432]

88. Magge SN, Stettler N, Koren D, Levitt Katz LE, Gallagher PR, Mohler ER 3rd, et al. Adiponectin Is Associated with Favorable Lipoprotein Profile, Independent of BMI and Insulin Resistance, in Adolescents. J Clin Endocrinol Metab. 2011; 96(5):1549-54. [PubMed: 21367935]

89. Beauloye V, Zech F, Tran HT, Clapuyt P, Maes M, Brichard SM. Determinants of early atherosclerosis in obese children and adolescents. J Clin Endocrinol Metab. 2007; 92(8):3025-32. [PubMed: 17519311]

90. Zhang Y, Proenca R, Maffei M, Barone M, Leopold L, Friedman JM. Positional cloning of the mouse obese gene and its human homologue. Nature. 1994; 372(6505):425-32. [PubMed: 7984236]

91. Beltowski J. Leptin and atherosclerosis. Atherosclerosis. 2006; 189(1):47-60. [PubMed: 16580676]

92. Considine RV, Sinha MK, Heiman ML, Kriauciunas A, Stephens TW, Nyce MR, et al. Serum immunoreactive-leptin concentrations in normal-weight and obese humans. N Engl J Med. 1996; 334(5):292-5. [PubMed: 8532024]

93. Wallace AM, McMahon AD, Packard CJ, Kelly A, Shepherd J, Gaw A, et al. Plasma leptin and the risk of cardiovascular disease in the west of Scotland coronary prevention study (WOSCOPS). Circulation. 2001; 104(25):3052-6. [PubMed: 11748099]

94. Ciccone M, Vettor R, Pannacciulli N, Minenna A, Bellacicco M, Rizzon P, et al. Plasma leptin is independently associated with the intima-media thickness of the common carotid artery. Int J Obes Relat Metab Disord. 2001; 25(6):805-10. [PubMed: 11439293]

95. Targher G, Bertolini L, Padovani R, Zenari L, Scala L, Cigolini M, et al. Serum 25hydroxyvitamin D3 concentrations and carotid artery intima-media thickness among type 2 diabetic patients. Clin Endocrinol (Oxf). 2006; 65(5):593-7. [PubMed: 17054459]

96. Diaz VA, Mainous AG 3rd, Carek PJ, Wessell AM, Everett CJ. The association of vitamin D deficiency and insufficiency with diabetic nephropathy: implications for health disparities. J Am Board Fam Med. 2009; 22(5):521-7. [PubMed: 19734398] 
97. Kaur H, Donaghue KC, Chan AK, Benitez-Aguirre P, Hing S, Lloyd M, et al. Vitamin D deficiency is associated with retinopathy in children and adolescents with type 1 diabetes. Diabetes Care. 2011; 34(6):1400-2. [PubMed: 21515836]

**98. Urbina EM, Williams RV, Alpert BS, Collins RT, Daniels SR, Hayman L, et al. Noninvasive assessment of subclinical atherosclerosis in children and adolescents: recommendations for standard assessment for clinical research: a scientific statement from the American Heart Association. Hypertension. 2009; 54(5):919-50. Scientific statement by the AHA describing the methodology for non-invasive vascular imaging techniques to assess CVD risk, and identifying gaps in the scientific evidence warranting further research. [PubMed: 19729599]

99. Bots ML, Hoes AW, Koudstaal PJ, Hofman A, Grobbee DE. Common carotid intima-media thickness and risk of stroke and myocardial infarction: the Rotterdam Study. Circulation. 1997; 96(5):1432-7. [PubMed: 9315528]

100. Chambless LE, Heiss G, Folsom AR, Rosamond W, Szklo M, Sharrett AR, et al. Association of coronary heart disease incidence with carotid arterial wall thickness and major risk factors: the Atherosclerosis Risk in Communities (ARIC) Study, 1987-1993. Am J Epidemiol. 1997; 146(6): 483-94. [PubMed: 9290509]

101. Leinonen ES, Hiukka A, Hurt-Camejo E, Wiklund O, Sarna SS, Mattson Hulten L, et al. Lowgrade inflammation, endothelial activation and carotid intima-media thickness in type 2 diabetes. Journal of Internal Medicine. 2004; 256(2):119-27. [PubMed: 15257724]

102. Esposito K, Giugliano D, Nappo F, Marfella R. Regression of carotid atherosclerosis by control of postprandial hyperglycemia in type 2 diabetes mellitus. Circulation. 2004; 110(2):214-9. [PubMed: 15197140]

103. Langenfeld MR, Forst T, Hohberg C, Kann P, Lubben G, Konrad T, et al. Pioglitazone decreases carotid intima-media thickness independently of glycemic control in patients with type 2 diabetes mellitus: results from a controlled randomized study. Circulation. 2005; 111(19):2525-31.

[PubMed: 15883215]

104. Meyer AA, Kundt G, Steiner M, Schuff-Werner P, Kienast W. Impaired Flow-Mediated Vasodilation, Carotid Artery Intima-Media Thickening, and Elevated Endothelial Plasma Markers in Obese Children: The Impact of Cardiovascular Risk Factors. Pediatrics. 2006; 117(5): 1560-7. [PubMed: 16651309]

105. Zhu W, Li M, Huang X, Neubauer H. Association of hyperviscosity and subclinical atherosclerosis in obese schoolchildren. European Journal of Pediatrics. 2005; 164(10):639-45. [PubMed: 16010562]

106. Stabouli S, Kotsis V, Papamichael C, Constantopoulos A, Zakopoulos N. Adolescent obesity is associated with high ambulatory blood pressure and increased carotid intimal-medial thickness. The Journal of Pediatrics. 2005; 147(5):651-6. [PubMed: 16291358]

107. Jarvisalo MJ, Putto-Laurila A, Jartti L, Lehtimaki T, Solakivi T, Ronnemaa T, et al. Carotid artery intima-media thickness in children with type 1 diabetes. Diabetes. 2002; 51(2):493-8. [PubMed: 11812760]

108. Peppa-Patrikiou M, Scordili M, Antoniou A, Giannaki M, Dracopoulou M, Dacou-Voutetakis C. Carotid atherosclerosis in adolescents and young adults with IDDM. Relation to urinary endothelin, albumin, free cortisol, and other factors. Diabetes Care. 1998; 21(6):1004-7. [PubMed: 9614622]

109. Krantz JS, Mack WJ, Hodis HN, Liu CR, Liu CH, Kaufman FR, et al. Early onset of subclinical atherosclerosis in young persons with type 1 diabetes. Journal of Pediatrics. 2004; 145(4):452-7. [PubMed: 15480366]

110. Singh TP, Groehn H, Kazmers A. Vascular function and carotid intimal-medial thickness in children with insulin-dependent diabetes mellitus. J Am Coll Cardiol. 2003; 41(4):661-5. [PubMed: 12598080]

111. Parikh A, Sochett EB, McCrindle BW, Dipchand A, Daneman A, Daneman D. Carotid artery distensibility and cardiac function in adolescents with type 1 diabetes. J Pediatr. 2000; 137(4): 465-9. [PubMed: 11035822]

112. Babar GS, Zidan H, Widlansky ME, Das E, Hoffmann RG, Daoud M, et al. Impaired endothelial function in preadolescent children with type 1 diabetes. Diabetes Care. 2011; 34(3):681-5. [PubMed: 21289230] 
113. Margeirsdottir HD, Stensaeth KH, Larsen JR, Brunborg C, Dahl-Jorgensen K. Early signs of atherosclerosis in diabetic children on intensive insulin treatment: a population-based study. Diabetes Care. 2010; 33(9):2043-8. [PubMed: 20530748]

114. Krebs A, Schmidt-Trucksass A, Doerfer J, Grulich-Henn J, Holder M, Hecker W, et al. Cardiovascular risk in pediatric type 1 diabetes: sex-specific intima-media thickening verified by automatic contour identification and analyzing systems. Pediatr Diabetes. 2012; 13(3):251-8. [PubMed: 21933316]

115. Celermajer DS, Sorensen KE, Gooch VM, Spiegelhalter DJ, Miller OI, Sullivan ID, et al. Noninvasive detection of endothelial dysfunction in children and adults at risk of atherosclerosis. Lancet. 1992; 340(8828):1111-5. [PubMed: 1359209]

116. Jarvisalo MJ, Ronnemaa T, Volanen I, Kaitosaari T, Kallio K, Hartiala JJ, et al. Brachial artery dilatation responses in healthy children and adolescents. Am J Physiol Heart Circ Physiol. 2002; 282(1):H87-92. [PubMed: 11748051]

117. Faulx MD, Wright AT, Hoit BD. Detection of endothelial dysfunction with brachial artery ultrasound scanning. Am Heart J. 2003; 145(6):943-51. [PubMed: 12796748]

118. Tounian P, Aggoun Y, Dubern B, Varille V, Guy-Grand B, Sidi D, et al. Presence of increased stiffness of the common carotid artery and endothelial dysfunction in severely obese children: a prospective study. Lancet. 2001; 358(9291):1400-4. [PubMed: 11705484]

119. Watts K, Beye P, Siafarikas A, Davis EA, Jones TW, O’Driscoll G, et al. Exercise training normalizes vascular dysfunction and improves central adiposity in obese adolescents. J Am Coll Cardiol. 2004; 43(10):1823-7. [PubMed: 15145107]

120. Jarvisalo MJ, Raitakari M, Toikka JO, Putto-Laurila A, Rontu R, Laine S, et al. Endothelial dysfunction and increased arterial intima-media thickness in children with type 1 diabetes. Circulation. 2004; 109(14):1750-5. [PubMed: 15023875]

121. Battelino N, Sebestjen M, Keber I, Blagus R, Hovnik T, Bratina N, et al. Endothelial nitric oxide synthase T(-786)C polymorphism in children and adolescents with type 1 diabetes and impaired endothelium-dependent dilatation. Horm Res Paediatr. 2011; 76(4):248-53. [PubMed: 21912080]

122. Aggoun Y, Szezepanski I, Bonnet D. Noninvasive assessment of arterial stiffness and risk of atherosclerotic events in children. Pediatr Res. 2005; 58(2):173-8. [PubMed: 16055929]

123. Wildman RP, Mackey RH, Bostom A, Thompson T, Sutton-Tyrrell K. Measures of obesity are associated with vascular stiffness in young and older adults. Hypertension. 2003; 42(4):468-73. [PubMed: 12953016]

124. Gungor N, Thompson T, Sutton-Tyrrell K, Janosky J, Arslanian S, Full SN, et al. Early signs of cardiovascular disease in youth with obesity and type 2 diabetes. Diabetes Care. 2005; 28(5): 1219-21. [PubMed: 15855596]

125. Urbina EM, Wadwa RP, Davis C, Snively BM, Dolan LM, Daniels SR, et al. Prevalence of increased arterial stiffness in children with type 1 diabetes mellitus differs by measurement site and sex: the SEARCH for Diabetes in Youth Study. J Pediatr. 2010; 156(5):731-7. 7, e1. [PubMed: 20097360]

126. Collins RT, Somes GW, Alpert BS. Differences in arterial compliance among normotensive adolescent groups: Collins arterial compliance in adolescents. Pediatr Cardiol. 2008; 29(5):92934. [PubMed: 18437445]

127. Reusz GS, Cseprekal O, Temmar M, Kis E, Cherif AB, Thaleb A, et al. Reference values of pulse wave velocity in healthy children and teenagers. Hypertension. 2010; 56(2):217-24. [PubMed: 20566959]

128. Shah AS, Dolan LM, Gao Z, Kimball TR, Urbina EM. Racial differences in arterial stiffness among adolescents and young adults with type 2 diabetes. Pediatr Diabetes. 2012; 13(2):170-5. [PubMed: 21790919]

129. Gunczler P, Lanes R, Soros A, Verdu L, Ramon Y, Guevara B, et al. Coronary artery calcification, serum lipids, lipoproteins, and peripheral inflammatory markers in adolescents and young adults with type 1 diabetes. J Pediatr. 2006; 149(3):320-3. [PubMed: 16939740] 
130. Starkman HS, Cable G, Hala V, Hecht H, Donnelly CM. Delineation of prevalence and risk factors for early coronary artery disease by electron beam computed tomography in young adults with type 1 diabetes. Diabetes Care. 2003; 26(2):433-6. [PubMed: 12547875]

131. Chinali M, de Simone G, Roman MJ, Lee ET, Best LG, Howard BV, et al. Impact of obesity on cardiac geometry and function in a population of adolescents: the Strong Heart Study. J Am Coll Cardiol. 2006; 47(11):2267-73. [PubMed: 16750694]

132. Levy D, Garrison RJ, Savage DD, Kannel WB, Castelli WP. Prognostic implications of echocardiographically determined left ventricular mass in the Framingham Heart Study. N Engl J Med. 1990; 322(22):1561-6. [PubMed: 2139921]

133. Koren MJ, Devereux RB, Casale PN, Savage DD, Laragh JH. Relation of left ventricular mass and geometry to morbidity and mortality in uncomplicated essential hypertension. Ann Intern Med. 1991; 114(5):345-52. [PubMed: 1825164]

134. Li X, Li S, Ulusoy E, Chen W, Srinivasan SR, Berenson GS. Childhood adiposity as a predictor of cardiac mass in adulthood: the Bogalusa Heart Study. Circulation. 2004; 110(22):3488-92. [PubMed: 15557363]

135. Urbina EM, Gidding SS, Bao W, Pickoff AS, Berdusis K, Berenson GS. Effect of body size, ponderosity, and blood pressure on left ventricular growth in children and young adults in the Bogalusa Heart Study. Circulation. 1995; 91(9):2400-6. [PubMed: 7729027]

136. Crowley DI, Khoury PR, Urbina EM, Ippisch HM, Kimball TR. Cardiovascular impact of the pediatric obesity epidemic: higher left ventricular mass is related to higher body mass index. $\mathrm{J}$ Pediatr. 2011; 158(5):709-14. e1. [PubMed: 21147488]

137. Khoury PR, Mitsnefes M, Daniels SR, Kimball TR. Age-specific reference intervals for indexed left ventricular mass in children. J Am Soc Echocardiogr. 2009; 22(6):709-14. [PubMed: 19423289]

138. Benitez-Aguirre P, Craig ME, Sasongko MB, Jenkins AJ, Wong TY, Wang JJ, et al. Retinal vascular geometry predicts incident retinopathy in young people with type 1 diabetes: a prospective cohort study from adolescence. Diabetes Care. 2011; 34(7):1622-7. [PubMed: 21593293]

139. Benitez-Aguirre PZ, Sasongko MB, Craig ME, Jenkins AJ, Cusumano J, Cheung N, et al. Retinal vascular geometry predicts incident renal dysfunction in young people with type 1 diabetes. Diabetes Care. 2012; 35(3):599-604. [PubMed: 22250064] 